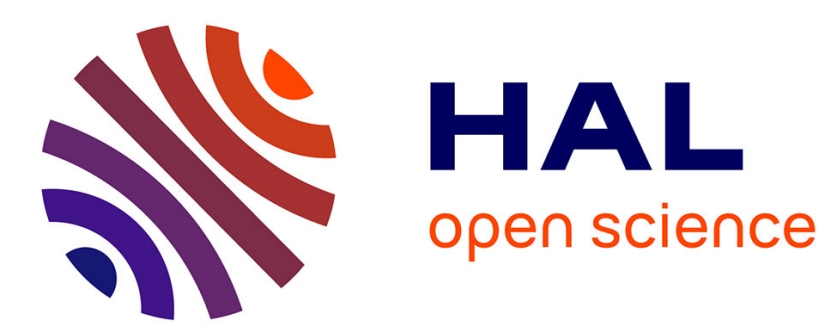

\title{
Evaluation of the flammability of gorse (Ulex europaeus L.) managed by prescribed burning
}

\author{
Madrigal, Marino, Guijarro, Hernando, Díez
}

\section{To cite this version:}

Madrigal, Marino, Guijarro, Hernando, Díez. Evaluation of the flammability of gorse (Ulex europaeus L.) managed by prescribed burning. Annals of Forest Science, 2012, 69 (3), pp.387-397. 10.1007/s13595-011-0165-0 . hal-00930736

\section{HAL Id: hal-00930736 https://hal.science/hal-00930736}

Submitted on 1 Jan 2012

HAL is a multi-disciplinary open access archive for the deposit and dissemination of scientific research documents, whether they are published or not. The documents may come from teaching and research institutions in France or abroad, or from public or private research centers.
L'archive ouverte pluridisciplinaire HAL, est destinée au dépôt et à la diffusion de documents scientifiques de niveau recherche, publiés ou non, émanant des établissements d'enseignement et de recherche français ou étrangers, des laboratoires publics ou privés. 


\title{
Evaluation of the flammability of gorse (Ulex europaeus L.) managed by prescribed burning
}

\author{
Javier Madrigal • Eva Marino • Mercedes Guijarro • \\ Carmen Hernando $\cdot$ Carmen Díez
}

Received: 14 June 2011 / Accepted: 15 November 2011 /Published online: 13 December 2011

(C) INRA / Springer-Verlag France 2011

\begin{abstract}
- Introduction The abandonment of rural areas has led to an increase of the fire-prone European gorse (Ulex europaeus L.) communities in some regions, where prescribed burning is a technique applied to control them. Understanding flammability changes after treatments is crucial for the sustainable use of fire.

- Objectives The objectives of this study were to evaluate (1) any differences in the flammability of gorse plant parts 1 and 5 years after burning and (2) the flammability of whole plants, assessing complementarities of the results between full-scale and bench-scale tests.

- Results Results showed the importance of the effect of the different scales and types of methods used to determine the four components of flammability of forest fuels: (1) Ignitability was highly dependent on the type of ignition source. (2) Combustibility was more dependent on the dead fraction than on live plant part characteristics. (3) Sustainability was mainly related to physical characteristics, like air flow interaction with fuel compactness. (4) Consumability, in terms of residual mass fraction, was similar at both scales.
\end{abstract}

\section{Handling Editor: Gilbert Aussenac}

Contributions of the co-authors J. Madrigal wrote the first version of the paper, carrying out experimental design, data analysis and discussion of the results. E. Marino contributed to the whole plant design experiments, data collection and reviewing the results and discussion. M. Guijarro and C. Hernando coordinated research projects in the frame of which the present work was conducted, participating on experimental design and reviewing the paper. C. Díez participated on laboratory assistance carrying out experimental tests.

J. Madrigal $(\bowtie) \cdot$ E. Marino $\cdot$ M. Guijarro $•$ C. Hernando • C. Díez Centro de Investigación Forestal, Instituto Nacional de Investigación y Tecnología Agraria y Alimentaria (INIA),

Ctra. de La Coruña km 7.5,

28040 Madrid, Spain

e-mail: incendio@inia.es
- Conclusions The results suggest the need for intensive management of gorse shrubland to maintain them at a very young age in order to reduce flammability associated with the rapid physiological and structural changes in this kind of vegetation.

Keywords Flammability $\cdot$ Ulex europaeus $\cdot$ Prescribed burning $\cdot$ Full-scale testing $\cdot$ Bench-scale testing $\cdot$ Mass loss calorimeter

\section{Introduction}

Communities dominated by European gorse (Ulex europaeus L.) are considered one of the most fire-prone types of shrubland because of the high rate of fuel accumulation and flammability of the species (Baeza et al. 2002). Wildfires in such communities can produce high-intensity fires that may be very difficult to control by fire fighting actions and thus pose a major threat to both human populations and forest resources. Fires have occurred naturally in the geographical area of gorse shrubland communities (Central and Western Europe) for millennia, and plant populations in these ecosystems have acquired adaptive mechanisms enabling them to persist and regenerate after recurrent fires (Pausas et al. 2008). In many cases, such adaptations have resulted in high species resilience as well as high species flammability, thus facilitating shrubland regeneration after fire disturbance.

Gorse has also spread and become a serious weed problem around the world, in, e.g. Australia, New Zealand, Chile, Costa Rica, Hawaii and Atlantic coastal areas of North America (Hoshovsky 1989). It is recognized as an invasive species because it can (1) fix nitrogen; (2) acidify and impoverish soils (at least temporarily) by taking up 
bases; (3) survive on a variety of soil types; (4) produce copious amounts of heat-tolerant seeds with long-term viability; and (5) regenerate rapidly from seeds and stumps after disturbances such as brush clearing and fires (Hoshovsky 1989). Spiny and mostly unpalatable when mature, gorse reduces pasture quality where it invades rangeland and excludes grazing animals from rangelands and pasture.

The abandonment of many rural areas in Europe and the higher incidence of forest fires have led to an increase in gorse shrubland in some regions, such communities being associated with a large number of fire ignitions and burnt areas. Preventive measures are therefore required to prevent forest fires occurring in adjacent areas. In addition, gorse control is also required by land owners and institutions in order to improve livestock grazing and wildlife habitats as well as to clear patches for hunting. The problem differs in many natural areas in Europe: when grassland is first abandoned, the grazing intensity is reduced or suppressed and gorse invades the area. Successful clearance of gorse requires a combination of methods including pasture management and appropriate follow-up treatments (i.e. herbicides). As the use of herbicides is restricted in European forest areas for ecological and socioeconomic reasons, the shrub control techniques most commonly used to reduce fire hazard and improve pasture areas involve the removal of plants by mechanical clearing or burning (Baeza et al. 2003). However, like many scrub weeds, gorse soon resprouts from dormant buds on stumps after brush clearing and burning. In this case, ploughing or repeated rotary treatment can be used.

Gorse, like other shrub fuels, often burns at very high rates of spread, leading to extremely intense fires associated with high levels of fire danger. Experimental equations (Anderson and Anderson 2010; Marino et al. 2011) have been developed to predict ignition risk and fire spread in gorse shrubland, to aid decisions concerning burn prescriptions and to support fire suppression actions. Although the efficiency of prescribed fire in reducing wildfire hazard is often mentioned as a matter of fact, there are still some uncertainties regarding the protective advantages provided, which limit the use of this technique (Fernandes and Botelho 2003). Fire has traditionally been used in Spain to control shrubland cover, especially to increase grazing areas. Therefore, a feedback process occurs in which gorse shrublands are maintained at relatively young stages either by the use of prescribed fire or by wildland fire events (Baeza et al. 2003; Pausas et al. 2008).

Few studies have addressed the effects of fire on shrub flammability (Marino et al. 2010; Anderson and Anderson 2010), and even fewer have investigated the fuels resulting from prescribed burning or wildfires (Marino et al. 2011). Some authors have studied the recovery of vegetation after several fuel treatments, including prescribed burning in shrubland (Calvo et al. 2002; Pereiras and Casal 2002; Baeza et al. 2003; Potts et al. 2010), but have not directly assessed the flammability of the resulting vegetation. Baeza et al. (2002) and De Luis et al. (2004) studied the fuel characteristics that influence fire behaviour in Mediterranean gorse shrubland of different ages, although they did not assess fuel flammability. Evaluation of flammability parameters may help forest managers and land owners, assessing the evolution of fire hazard in order to plan the frequency of prescribed burning (Marino et al. 2011) or improving the predictive ability of forest fire behaviour models based on physical plant parameters (Sullivan 2009).

Flammability can be considered as a complex process divided into four components proposed by Anderson (1970) and Martin et al. (1994): ignitability, sustainability, combustibility and consumability. The lack of independence between the four components adds to the complexity of quantifying flammability and of developing a standardized method for doing so (White and Zipperer 2010). Doran et al. (2004) identified three levels of forest fuel specimens to address flammability: plant parts, whole plants and groups of plants. Bench-scale tests using standard test methods for building materials have been proposed to measure the flammability of plant parts, with good results (Weise et al. 2005; Dibble et al. 2007; Schemel et al. 2008; Madrigal et al. 2009). Intermediate- and large-scale experiments for evaluating flammability of whole plants (Etlinger and Beall 2004; Weise et al. 2005; Babrauskas 2006) are less frequent because of technological (full-scale devices) and methodological constraints, such as how size, shape, arrangement and plant condition (health, moisture content, necromass) affect heat release (Etlinger and Beall 2004). In addition, plants used in whole-plant analyses are usually obtained from nurseries and are therefore in excellent condition (no dieback disease, low level of necromass and relatively uniform in shape), which is not often observed in the field (White and Zipperer 2010). Field experiments with groups of plants (Anderson and Anderson 2010) corroborate the significant effect of elevated dead fuel (necromass and decaying parts) on ignition and fire spread thresholds in gorse shrubland. Therefore, the complexity of 'real-world' conditions must be considered in model development (Beverly and Wotton 2007). The 3D shape of plant samples affects how they are heated by convection and radiation (White and Zipperer 2010), which in turn affects their flammability (Schemel et al. 2008; Madrigal et al. 2009, 2011a).

Baeza et al. (2002) observed differences between young and mature stands of another type of gorse shrubland (Ulex parviflorus Pourr.) in relation to fuel moisture. The authors explained that the lower moisture levels in mature stands were due to the lower water content of live tissues as well as to the higher fraction of necromass in older shrubs. Moreover, a recent study (Marino et al. 2011) showed that 
fire was not sustained in 1-year-old $U$. europaeus shrubs regenerated after prescribed burning, whereas high probabilities of ignition and initial propagation were observed in 3and 5-year-old shrubs. The results indicated that resprouting age and fuel moisture significantly affected ignition and initial propagation success of post-fire regenerated shrub fuels. These results also suggest that physiological changes after burning may produce large increases in flammability within a short time after disturbance.

The present study focuses on gorse plants regenerated after prescribed burning. The aims of the study were (1) to evaluate any differences in the flammability of gorse plant parts 1 and 5 years after burning and (2) to evaluate the flammability of whole plants ( 1 and 5 years old), assessing the complementarities of results between full-scale and bench-scale tests.

\section{Materials and methods}

\subsection{Fuel sampling}

A gorse shrubland community where spring prescribed burnings had been conducted 1 and 5 years earlier (in adjacent areas) was selected for study. The experimental site is located in Pontevedra, Galicia (NW Spain; 42 $38^{\prime} 50^{\prime \prime}$ $\mathrm{N}, 8^{\circ} 29^{\prime} 0^{\prime \prime} \mathrm{W}$ ). The mean elevation is $550 \mathrm{~m}$ and the mean slope $10 \%$, with an eastern aspect. The average annual temperature and precipitation are $12^{\circ} \mathrm{C}$ and $1,200 \mathrm{~mm}$, respectively. Before prescribed burning, the vegetation was a homogeneous shrubland of average cover $100 \%$, dominated by $U$. europaeus.

In areas covered by regenerated shrubs, vegetation samples $(1 \times 1 \mathrm{~m})$ including the litter underlying the shrub layer were collected. Shrubs were cut at the base of the stems and stored carefully in order to preserve their field structure as well as possible. Fuel sampling was carried out during the fire season (from June to October) with the aim of assessing the effect of physiology on vegetation flammability and selecting low fuel moisture contents corresponding to high levels of fire hazard. All fuel samples were transported in plastic bags to the laboratory to avoid loss of water content. The characteristics of these wholeplant samples are described in Table 1.

In order to characterize the flammability of plant parts, subsamples from whole plants were collected. Plants were divided into three parts according to the visually observed physiological state: live parts (green leaves), decaying parts (leaves and twigs in a process of decay, with some green leaves) and dead parts (necromass with dried leaves and twigs). As most forest fire behaviour models and experimental estimates (Sullivan 2009) assume that most of the fuel consumed during an
Table 1 Characteristics of the whole-plant samples tested in the wind tunnel (mean \pm standard error)

\begin{tabular}{llc}
\hline Sample type & \multicolumn{2}{l}{ Shrub age } \\
\cline { 2 - 3 } Whole plant $(1 \times 1 \mathrm{~m})$ & 1 year & 5 years \\
\hline FMC_live parts $(\%)$ & $99.5( \pm 4)$ & $72( \pm 11)$ \\
FMC_decaying parts $(\%)$ & n.a. & $45( \pm 15)$ \\
FMC_dead parts $(\%)$ & n.a. & $18( \pm 3.5)$ \\
H_total $(\mathrm{mm})$ & $235( \pm 20)$ & $452( \pm 51)$ \\
H_dead $(\mathrm{mm})$ & n.a. & $347( \pm 27)$ \\
Load $\left(\mathrm{kg} / \mathrm{m}^{2}\right)$ & $1.6( \pm 0.1)$ & $3.1( \pm 0.1)$ \\
Bulk density $\left(\mathrm{kg} / \mathrm{m}^{3}\right)$ & $7.9( \pm 0.5)$ & $7.1( \pm 0.8)$ \\
\hline
\end{tabular}

FMC fuel moisture content (expressed as a percentage on an ovendried weight basis; $48 \mathrm{~h}$ at $100^{\circ} \mathrm{C}$ ), $H$ height, n.a. not applicable

active flaming fire is of diameter $<10 \mathrm{~mm}$, plant parts of this fuel size were cut from the whole plants to prepare the samples for use in the bench-scale tests $(100 \times 100 \times 50 \mathrm{~mm})$. This criterion has also been assumed by several authors to assess flammability in bench-scale tests (e.g. Weise et al. 2005; Dibble et al. 2007; White and Zipperer 2010).

\subsection{Experimental procedures}

Burning tests were performed in different experimental devices according to the type and size of the fuel complex assessed (Fig. 1): plant parts were assessed in bench-scale tests, in a mass loss calorimeter device and in an oxygen bomb calorimeter, whereas whole plants were assessed in full-scale tests in an outdoor wind tunnel.

According to Dibble et al. (2007) and White and Zipperer (2010), the flammability of plant parts can be measured in bench-scale standard test methods used to determine the flammability properties of building materials. In the present study, plant parts were tested with a mass loss calorimeter device (see Madrigal et al. 2009 for details). The output variables produced by this apparatus can be used to evaluate flammability components, as defined by Anderson (1970) and Martin et al. (1994). The device used in the present study was equipped with a porous sample holder specifically adapted for forest fuel samples (Schemel et al. 2008). The holder has uniformly-sized, evenly distributed holes (Fig. 1) which create an open area $(63 \%$ porosity) for inlet combustion gases in order to simulate a more realistic rapid flaming combustion and to approximate the test conditions to 3D reality. This methodology has been applied to forest fuels, with quite accurate results (Schemel et al. 2008; Madrigal et al. 2009, 2011a), and is considered a good method for characterizing flammability outputs related to physical processes such as convection and transport of combustion gases. The samples were exposed to a constant heat flux of $50 \mathrm{~kW} / \mathrm{m}^{2}$; a piloted ignition was used. The bulk 

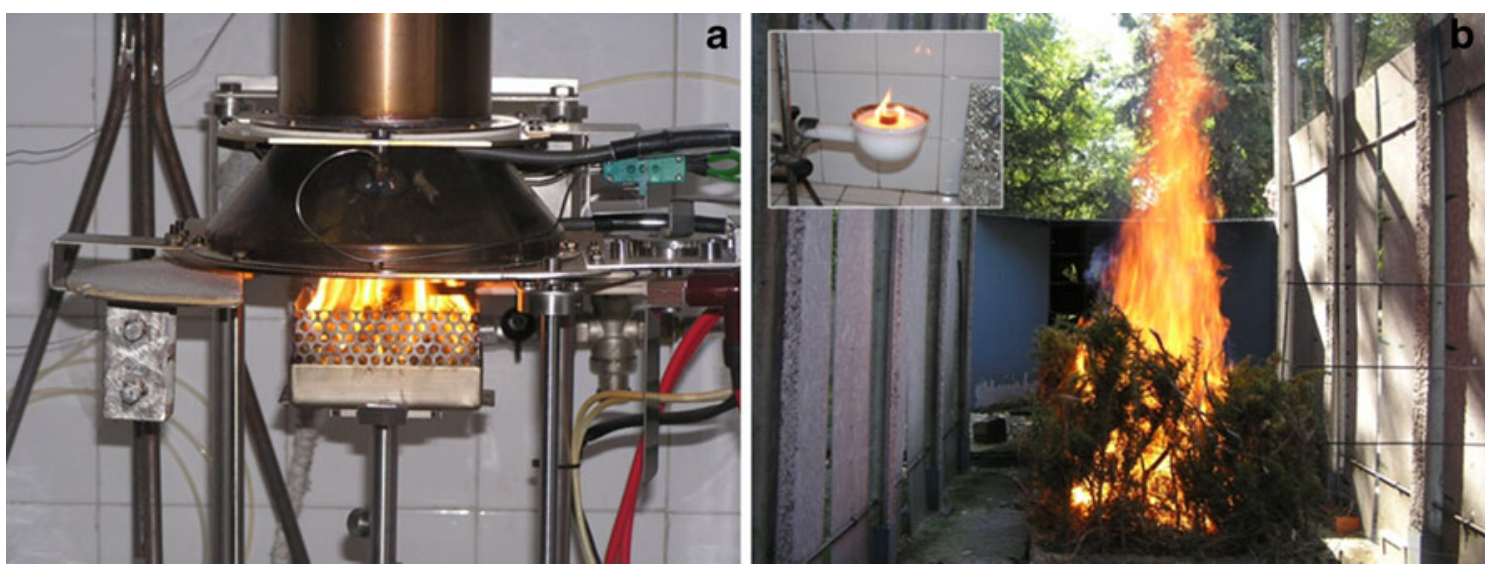

Fig. 1 Experimental devices used to evaluate flammability (a) at bench scale (mass loss calorimeter with the porous holder) and (b) at full scale (outdoor wind tunnel and epiradiator with the flaming firebrand used as point ignition source, top inset)

density was fixed at $20 \mathrm{~kg} / \mathrm{m}^{3}$ in all tests (i.e. fuel samples of $10 \mathrm{~g}$ on a dry weight basis) in order to compare flammability outputs (Enninful and Torvi 2005) because heat release is strongly affected by the initial mass of the tested samples (Madrigal et al. 2009). At least three replicates that complied with the repeatability criteria were considered for each plant part. Another series of tests was carried out with an oxygen bomb calorimeter to determine the gross heat of combustion (GHC), following ISO standard 1716 (ISO 1995). The values obtained provide information about the chemistry of combustion process because GHC is related to volatile, resin and lignin contents (White 1987).

Whole plants were tested in an outdoor wind tunnel (see Madrigal et al. 2011b for details). Flammability parameters were analysed in 1- and 5-year-old shrubs. Shrub samples were reconstructed in one of the wagons in the central part of the test section, in accordance with the original fuel complex structure found in the field (i.e. fuel load and bulk density). Before testing, shrub samples were stored in a cold chamber $\left(\right.$ at $4^{\circ} \mathrm{C}$ ) to delay loss of water content and were tested within 2-5 days of collection of the fuel in the field. The tests were performed in the absence of wind, with air temperature ranging from $23^{\circ} \mathrm{C}$ to $27^{\circ} \mathrm{C}$ and relative air humidity ranging from $46 \%$ to $51 \%$. Fuel loads tested were calculated according to the fresh weights and the respective fuel moisture content (FMC) values obtained from samples collected immediately before each test (Table 1 ). A piece of pine wood $(20 \times 20 \times 10 \mathrm{~mm})$ was ignited with an epiradiator (Fig. 1) and used as a flaming point ignition source (Ganteaume et al. 2009; Marino et al. 2010, 2011), which was dropped in the middle of the fuel samples. In order to measure the temperature during the tests, a vertical line of type $\mathrm{K}$ thermocouples (1-mm diameter) was placed in the middle of the wagon in which the fuel complex was reconstructed, at different heights over the litter $(0,0.25,0.50$, 0.75 and $1 \mathrm{~m}$ ). A data logger was used to record data at a frequency of $1 \mathrm{~s}$. Each experiment was replicated at least five times in order to obtain three replicates that complied with the repeatability criteria (Madrigal et al. 2009).

\subsection{Flammability parameters and data analysis}

Although there is no standard method for evaluating the four flammability components at different scales, White and Zipperer (2010) proposed potential test responses to characterize flammability components. A group of these responses was selected for use in the present study (Table 2).

The full-scale rate of heat release (HRR, in kilowatts per square metre) was obtained from the equation proposed by Wickström and Göransson (1987):

$\operatorname{HRR}_{f}=\sum_{t=1}^{t=N} \Delta A^{i} \operatorname{HRR}_{b}{ }^{N-i}$

where $\mathrm{HRR}_{\mathrm{f}}$ is the full-scale heat release (in kilowatts), $\Delta A^{i}$ is the incremental burning area growth at the time incremental $i$ (in square metres), and $\mathrm{HRR}_{\mathrm{b}}{ }^{N-i}$ is the heat release rate per unit area (in kilowatts per square metre) after $N-1$ time increments of the same length, recorded in the bench-scale calorimeter tests. In this case, the point ignition source that was dropped in the middle of the sample produced a radial burning area growth. But, for simplification, $\Delta A^{i}$ was assumed to be constant for each full-scale test according to the rate of spread during the flaming phase (observed visually); hence, burning area growth was equivalent to an incremental area resulting from a central fire line front burning simultaneously each half of the sample at a steady rate of spread. $\mathrm{HRR}_{\mathrm{b}}{ }^{N-i}$ was registered for each plant part (dead, decaying and live parts) during the mass loss calorimeter tests with a 1-s frequency. Heterogeneous composition of whole plants was considered by using a weighted average of bench-scale HRR values obtained for each plant part according to the 
Table 2 Parameters selected for the analysis of different flammability components in the experimental tests (adapted from White and Zipperer 2010)

${ }^{a}$ Variables measured in bench-scale tests (mass loss calorimeter) to characterize plant parts

${ }^{\mathrm{b}}$ Variables measured in full-scale tests (wind tunnel) to characterize whole plant

${ }^{\mathrm{c}}$ Average value corresponding to the duration of the flaming phase

${ }^{\mathrm{d}}$ Obtained in an oxygen bomb calorimeter

\begin{tabular}{lll}
\hline Components & Test responses & Units \\
\hline Ignitability & Ignition time (TTI) ${ }^{\mathrm{a}, \mathrm{b}}$ & $\mathrm{s}$ \\
Combustibility & Visual flame height $(\mathrm{FH})^{\mathrm{b}}$ & $\mathrm{cm}$ \\
& Rate of temperature increase (RTI) ${ }^{\mathrm{a}, \mathrm{b}}$ & ${ }^{\circ} \mathrm{C} / \mathrm{s}$ \\
& Rate of heat release (HRR) ${ }^{\mathrm{a}, \mathrm{b}, \mathrm{c}}$ & $\mathrm{kW} / \mathrm{m}^{2}$ \\
& Peak temperature and time to reach this (PT, t_PT) ${ }^{\mathrm{b}}$ & ${ }^{\circ} \mathrm{C}, \mathrm{s}$ \\
Sustainability & Peak heat release rate and time to reach this (PHRR, t_PHRR) $)^{\mathrm{a}}$ & $\mathrm{kW} / \mathrm{m}^{2}, \mathrm{~s}$ \\
& Duration of visual flaming (FD) $)^{\mathrm{a}, \mathrm{b}}$ & $\mathrm{s}$ \\
& Duration of elevated temperatures $(T>300)^{\mathrm{b}}$ & $\mathrm{s}$ \\
& Total heat release (THR) & $\mathrm{MJ} / \mathrm{m}^{2}$ \\
& Average effective heat of combustion $(\mathrm{AEHC})^{\mathrm{a}, \mathrm{b}}$ & $\mathrm{MJ} / \mathrm{kg}$ \\
Consumability & Gross heat of combustion $(\mathrm{GHC})^{\mathrm{a}, \mathrm{d}}$ & $\mathrm{MJ} / \mathrm{kg}$ \\
& Mass loss rate (MLR) & $\mathrm{g} / \mathrm{s}$ \\
& Residual mass fraction $(\mathrm{RMF})^{\mathrm{a}, \mathrm{b}}$ & $\%$
\end{tabular}

proportion of each fuel fraction present in the field. $H_{R R}$ was expressed relative to the burned area (test section of $0.8 \mathrm{~m}^{2}$ )

An approximation of the full-scale average effective heat of combustion (AEHC, in megajoules per kilogram) was obtained as:

$\mathrm{AEHC}=\frac{\sum_{t=0}^{t=e} \operatorname{HRR}_{f} \cdot \Delta t}{m_{0}-m_{e}}$

where $\mathrm{HRR}_{\mathrm{f}}$ is the full-scale heat release (Eq. 1), $\Delta t$ is the sampling time interval (in this case the test duration), $e$ is the end time of the test, $m_{0}$ is the mass of specimen at the beginning of test, and $m_{e}$ is the mass of specimen at the end of test.

The parameters assessed for each flammability component are shown in Table 2. Ignition time (TTI), flame height (FH) and flaming duration (FD) were determined visually. The residual mass fraction (RMF) was calculated by the differences between the weight of the samples at the beginning and at the end of the tests. The other variables were measured with the mass loss calorimeter (bench-scale tests) or with the thermocouples (full-scale tests). Timedependent variables were plotted (Fig. 2) and curves analysed in order to determine the flammability parameters (Smith 1996). All variables were calculated during the flaming phase because such data can be considered more representative of wildfire behaviour (Babrauskas 2006; Madrigal et al. 2011a).

In order to evaluate the effect of physiology on flammability components, non-parametric tests (KruskallWallis, Spearman) were applied to assess the differences between the values of bench-scale parameters in relation to plant part (dead parts, decaying parts and live parts) and shrub age (1- and 5-year-old resprouted shrubs). To retrieve potential complementarities and limitations of both scales, a qualitative assessment of the different results obtained from each method (bench-scale and full-scale tests) is also addressed for a selected group of common flammability parameters (Table 2).

\section{Results}

\subsection{Bench-scale tests}

Results from bench-scale tests showed large differences in flammability parameters depending on the plant part and shrub age (Table 3). Five-year-old plant parts were divided into the three physiological states selected (live, decaying and dead parts), whereas 1-year-old resprouts consisted of only live fuel. In addition, FMC observed in live parts from 5 -year-old resprouts was lower than in 1-year-old plants. The GHC was significantly lower in less lignified tissues, i.e. lower in 1-year-old plants than in 5-year-old plants. Both ignition time (TTI, ignitability) and time to peak of HRR (combustibility) were significantly higher in live parts than in dead and decaying parts. On the contrary, HRR, PHRR (combustibility) and total heat release (THR, sustainability) were significantly higher in dead and decaying parts than in live parts. As regards consumability, mass loss rate (MLR) and RMF were similar in the different plant parts, irrespectively of the FMC values. Other flammability variables such as rate of temperature increase (RTI), FD and AEHC (mass loss calorimeter) differed less in relation to plant part or shrub age. Therefore, TTI, time to PHRR, HRR, PHRR and THR were the most important variables for assessing differences in flammability between plant parts and for describing the temporal increase in gorse flammability (Fig. 3). FMC was strongly correlated (Spearman non-parametric corre- 


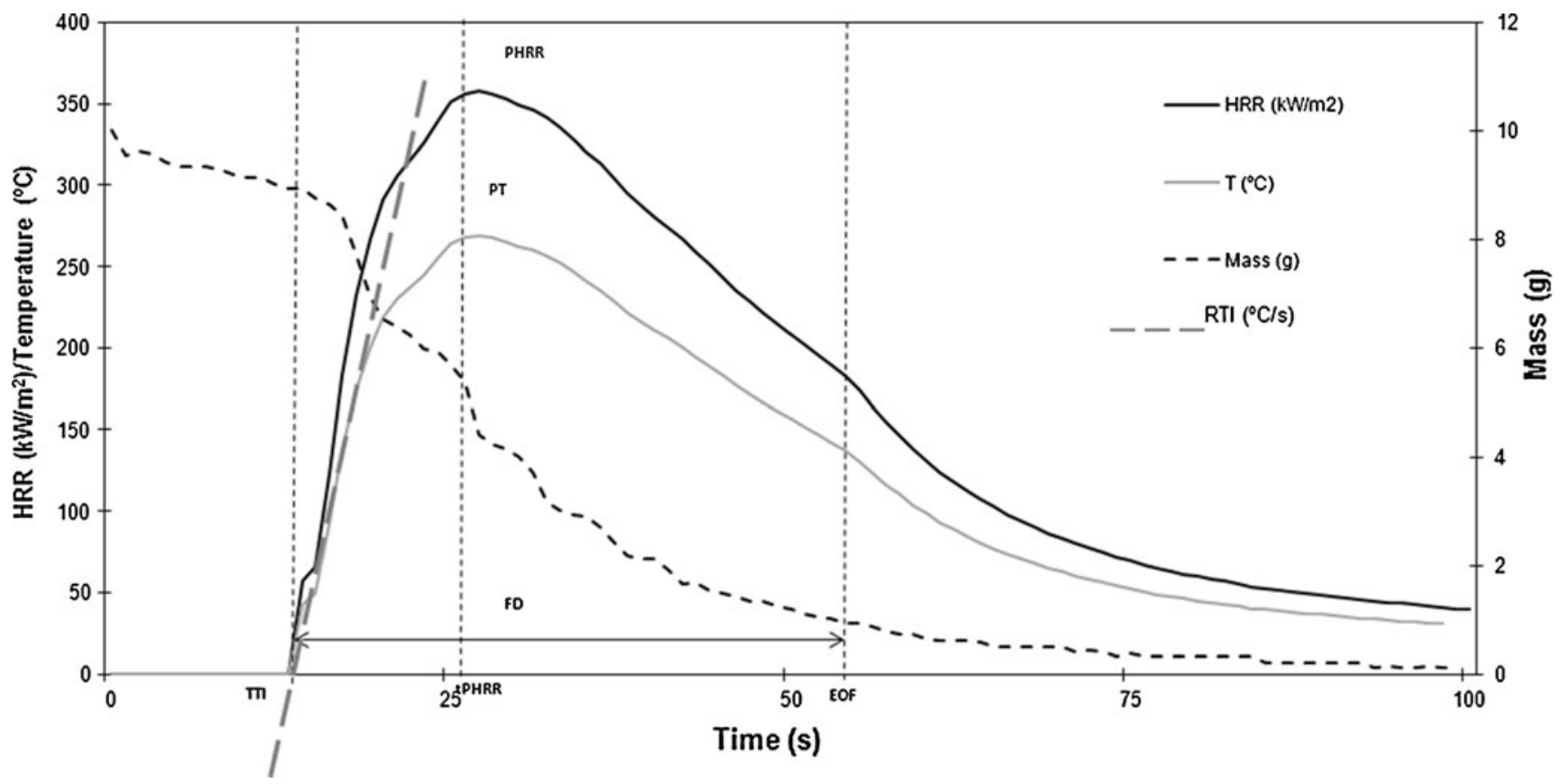

Fig. 2 Time-dependent plotted variables in bench-scale tests. Heat release rate $(H R R)$, temperature (T, first $y$-axis) and mass lost (second $y$-axis) during tests are shown. Vertical lines represent time to ignition

lation) with ignitability, combustibility and sustainability (Fig. 4), but not with consumability ( $r=-0.6, p=0.208)$.

\subsection{Full-scale tests and qualitative assessment of both scales}

Results from full-scale tests showed that the values of the flammability parameters were very different in $1-$ and 5 -

Table 3 Gorse flammability parameters measured in bench-scale tests: mass loss calorimeter device (repeatability criteria according to Babrauskas 2002, three replicates for each test) and oxygen bomb
(TTI), time to peak HRR ( $\left.t_{-} P H R R\right)$ and end of flame $(E O F)$. The rate of temperature increase $(R T I)$ is represented as a $T$ curve

year-old gorse shrubs. The high ignition time (i.e. low ignitability) of 1-year-old resprouts generated very few successful tests (one of ten replicates), which hindered calculation of the other flammability variables and precluded the application of statistical tests. Conversely, the number of successful tests was higher in the 5-year-old resprouts $(60 \%)$ with a very low TTI (i.e. high ignitability);

calorimeter (GHC, repeatability limit $150 \mathrm{~kJ} / \mathrm{kg}$ according to ISO 1716, three replicates for each test)

\begin{tabular}{|c|c|c|c|c|c|c|c|}
\hline \multicolumn{2}{|c|}{ Flammability components } & \multicolumn{4}{|c|}{ 5-year-old shrubs } & \multirow{2}{*}{\multicolumn{2}{|c|}{$\frac{\text { 1-year-old shrubs }}{\text { Live parts }}$}} \\
\hline & & \multirow{2}{*}{$\begin{array}{l}\text { Dead parts } \\
\mathrm{FMC}=25 \%\end{array}$} & \multicolumn{2}{|c|}{ Decaying parts } & \multirow{2}{*}{$\begin{array}{l}\text { Live parts } \\
\text { FMC }=75 \%\end{array}$} & & \\
\hline & & & $\mathrm{FMC}=40 \%$ & $\mathrm{FMC}=50 \%$ & & $\mathrm{FMC}=90 \%$ & $\mathrm{FMC}=110 \%$ \\
\hline Ignitability & TTI (s) & $17 \mathrm{a}$ & $22 b$ & $37 b$ & $58 \mathrm{c}$ & $51 \mathrm{c}$ & $58 \mathrm{c}$ \\
\hline \multirow[t]{4}{*}{ Combustibility } & $\mathrm{RTI}\left({ }^{\circ} \mathrm{C} / \mathrm{s}\right)$ & $27 \mathrm{a}$ & $21 b$ & $21 b$ & $16 \mathrm{~b}$ & $22 b$ & $21 b$ \\
\hline & HRR $\left(\mathrm{kW} / \mathrm{m}^{2}\right)$ & $235 \mathrm{a}$ & $176 b$ & $191 b$ & $145 \mathrm{c}$ & $156 \mathrm{c}$ & $132 \mathrm{c}$ \\
\hline & PHRR $\left(\mathrm{kW} / \mathrm{m}^{2}\right)$ & $331.6 \mathrm{a}$ & $263.5 b$ & $249.3 b$ & $190.5 \mathrm{c}$ & $198.1 \mathrm{c}$ & $217.7 \mathrm{c}$ \\
\hline & t_PHRR (s) & $29.5 \mathrm{a}$ & $35.5 \mathrm{a}$ & $50.5 \mathrm{~b}$ & $77.0 \mathrm{c}$ & $68.5 \mathrm{c}$ & $70.5 \mathrm{c}$ \\
\hline \multirow[t]{4}{*}{ Sustainability } & $\mathrm{FD}(\mathrm{s})$ & $49.5 \mathrm{a}$ & $51 \mathrm{a}$ & $45.5 \mathrm{a}$ & $42.5 \mathrm{a}$ & $42.5 \mathrm{a}$ & $58 \mathrm{a}$ \\
\hline & THR $\left(\mathrm{MJ} / \mathrm{m}^{2}\right)$ & $11.5 \mathrm{a}$ & $9.0 \mathrm{~b}$ & $8.7 b$ & $6.2 \mathrm{c}$ & $6.1 \mathrm{c}$ & $7.5 \mathrm{c}$ \\
\hline & AEHC (MJ/kg) & $14.3 \mathrm{a}$ & $12.3 \mathrm{~b}$ & $12.3 b$ & $11.4 \mathrm{~b}$ & $10.2 b$ & $13.1 \mathrm{~b}$ \\
\hline & GHC (MJ/kg) & $22.77 \mathrm{a}$ & $22.08 \mathrm{a}$ & $22.08 \mathrm{a}$ & $22.04 \mathrm{a}$ & $20.91 b$ & $20.91 b$ \\
\hline \multirow[t]{2}{*}{ Consumability } & $\operatorname{MLR}(\mathrm{g} / \mathrm{s})$ & $0.17 \mathrm{a}$ & $0.14 \mathrm{a}$ & $0.16 \mathrm{a}$ & $0.13 \mathrm{a}$ & $0.14 \mathrm{a}$ & $0.10 \mathrm{a}$ \\
\hline & RMF (\%) & $9.3 \mathrm{a}$ & $12.2 \mathrm{a}$ & $7.5 \mathrm{a}$ & $9.7 \mathrm{a}$ & $9.2 \mathrm{a}$ & $4.2 \mathrm{~b}$ \\
\hline
\end{tabular}

Different letters indicate significant differences at $p<0.05$ (non-parametric Kruskall-Wallis test) 


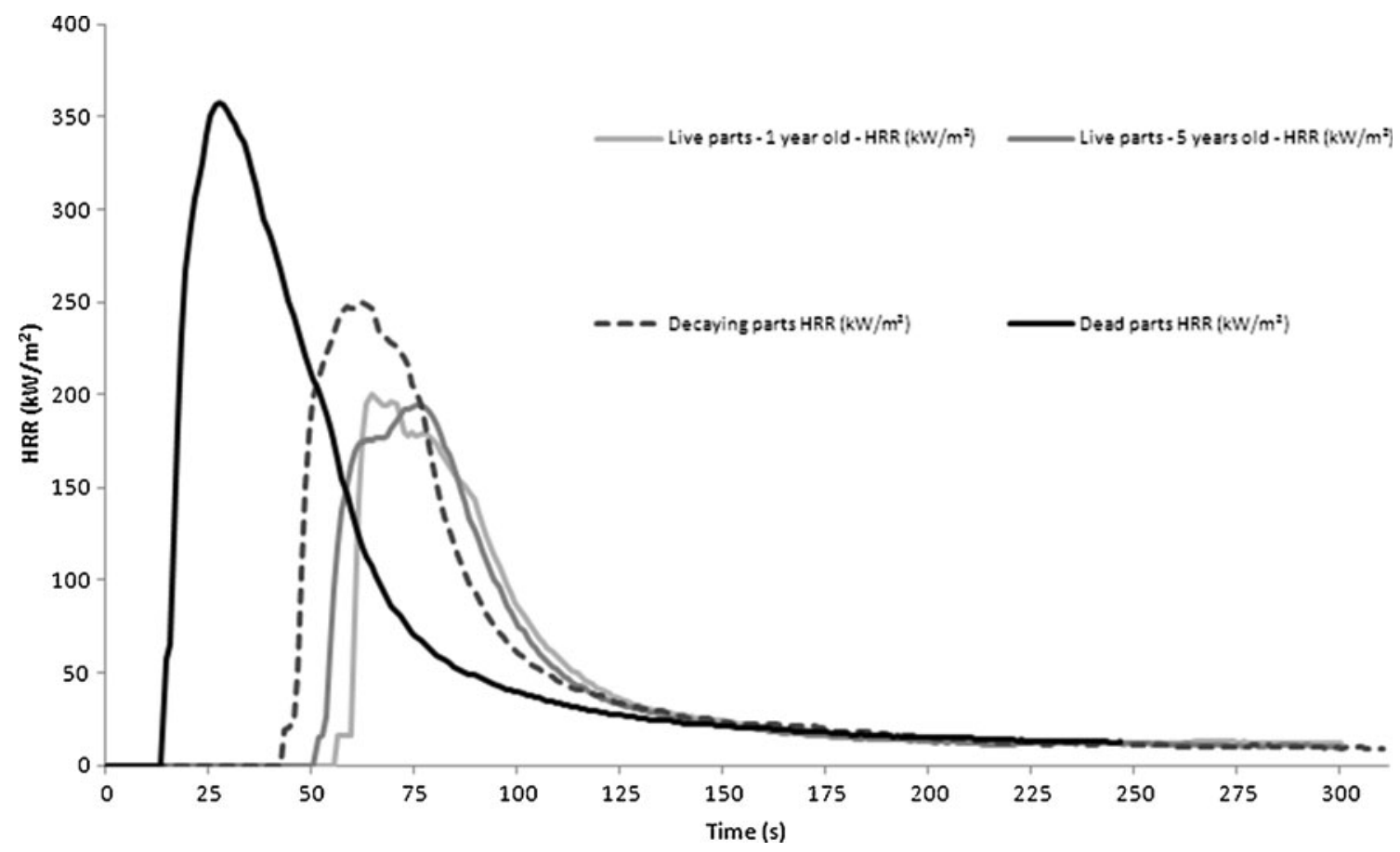

Fig. 3 HRR curves constructed with data obtained in mass loss calorimeter tests (heat flux, $50 \mathrm{~kW} / \mathrm{m}^{2}$; bulk density, $20 \mathrm{~kg} / \mathrm{m}^{3}$; piloted ignition; $y$ axis heat release rate; $x$-axis time in seconds)

higher FH, peak temperature (PT) and RTI (i.e. higher combustibility); higher FD and duration of elevated temperatures $T>300$ (i.e. higher sustainability); and lower RMF (i.e. higher consumability; Table 4). Qualitative assessment of the results obtained in both types of test (bench-scale vs. fullscale) with 5-year-old resprouts highlighted important differences in all variables, except for RTI and RMF for which similar values were obtained with whole plants in full-scale tests and with plant parts in bench-scale tests despite the differing experimental methodologies. However, the effect of scale and the type of method used on flammability parameters varied greatly depending on the variable considered, although large differences in the orders of magnitude between both scales were only observed in certain variables (e.g. FD, MLR).

\section{Discussion}

The differences in flammability in relation to plant structure and physiology (Tables 1 and 3) are consistent with field observations in other young and mature gorse stands ( $U$. parviflorus; Baeza et al. 2002). Expected differences between bench-scale and full-scale results confirm the difficulties in comparing both scales (Weise et al. 2005). Not only the ignition process but also the spatial distribution of the fuel elements is different, which hinders any direct comparison of quantitative values from the two experimental devices. Despite the correlations between the results from mass loss calorimeter and the results from tests with whole plants or natural fires not having been demonstrated (White and Zipperer 2010), the complementary information provided by bench-scale and full-scale tests in the present study may help in the integration and discussion of such results, considering that the proposed full-scale method is a reasonable simulation of field conditions (Marino et al. 2011).

The ignitability values obtained for gorse resprouts were in the upper range of values reported for bench-scale tests (low values of TTI). However, the various techniques used by different authors preclude a comparison of results. Weise et al. (2005) obtained TTI values ranging from 99 to $292 \mathrm{~s}$ for green samples $(\mathrm{FMC}=58-325 \%)$ in cone calorimeter tests with a heat flux of $25 \mathrm{~kW} / \mathrm{m}^{2}$. Dibble et al. (2007) detected TTI ranging from 15 to $203 \mathrm{~s}$ for a series of individual dried plant parts (FMC $=7-10 \%)$ using a similar methodology. Other authors who used the same methodology as in the present study reported TTI values ranging from 3 to $17 \mathrm{~s}$ for oven-dried samples and from 103 to $120 \mathrm{~s}$ for live plant parts (Madrigal et al. 2010, 2011a). The correlation between TTI and FMC was significant (Fig. 4), which is consistent with the significant effect of physiological changes on ignitability detected by Weise et al. (2005) and the effect of FMC on TTI reported in previous studies (e.g. Etlinger and Beall 2004; Dibble et al. 2007).

The full-scale results (Table 4) confirm the low ignitability of 1 -year-old shrubs in comparison with 5 -year-old shrubs. Ignition success was $10 \%$ and $60 \%$ for 1 - and 5- 

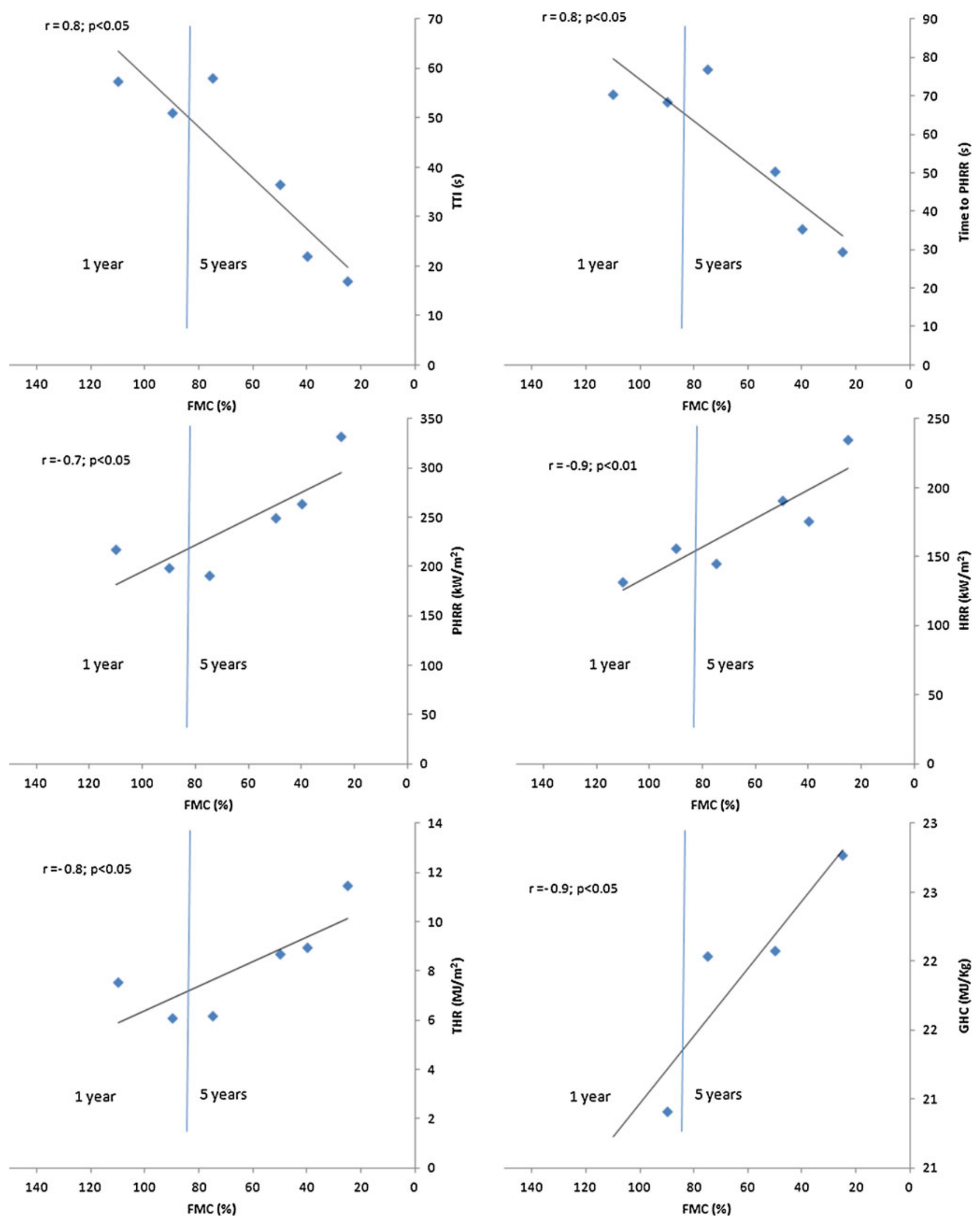

Fig. 4 Flammability patterns in gorse resprouts (after prescribed burning), in relation to FMC and shrub age ( 1 or 5 years), determined in benchscale tests. Non-parametric Spearman correlations are shown 
Table 4 Flammability parameters of 1- and 5-year-old shrubs measured in full-scale tests

\begin{tabular}{llcr}
\hline Flammability components & Variables & \multicolumn{2}{l}{ Shrub age } \\
\cline { 3 - 4 } & & 1 year & 5 years \\
\hline Ignitability & & 128 & $7(10)$ \\
Combustibility & TTI $(\mathrm{s})$ & 10 & $400(25)$ \\
& FH $(\mathrm{cm})$ & 47 & $953(22)$ \\
& PT $\left({ }^{\circ} \mathrm{C}\right)$ & 84 & $134(31)$ \\
Sustainability & $\mathrm{t} P T(\mathrm{~s})$ & 1.1 & $27(1.5)$ \\
& RTI $\left({ }^{\circ} \mathrm{C} / \mathrm{s}\right)$ & 17 & $235(54)$ \\
& FD $(\mathrm{s})$ & 0 & $113(11)$ \\
& $T>300(\mathrm{~s})$ & n.c. & $96(24)$ \\
Consumability & $\mathrm{HRR}\left(\mathrm{kW} / \mathrm{m}^{2}\right)$ & n.c. & $4.47(1.09)$ \\
& AEHC $(\mathrm{MJ} / \mathrm{kg})$ & 99.5 & $13.80(1.47)$ \\
& RMF $(\%)$ & n.c. & $21.53(1.87)$ \\
\hline
\end{tabular}

year-old resprouts, respectively, and no propagation was observed 1 year after burning. Weise et al. (2005) observed that in many instances, the green samples did not sustain ignition with $25 \mathrm{~kW} / \mathrm{m}^{2}$ radiant heat flux. In a previous study in which a point ignition source was used, Marino et al. (2011) obtained $33 \%$ and $75 \%$ of successful ignition tests for 1 - and 5-year-old shrubs and initial propagation success of $0 \%$ and $63 \%$, respectively. Logistic models to predict ignition and initial propagation success probabilities revealed that time since burning and fuel moisture content had significant effects on these parameters. The present results (Fig. 4 and Table 4) confirm the predictions of the aforementioned models. The results of full-scale tests showed that a flaming ignition source did not allow the combustion of 1-year-old resprouts, whereas the same ignition source generated an extremely rapid ignition (TTI of $7 \mathrm{~s}$ ) in 5-year-old resprouts. Live plant parts with a high physiological activity and high FMC require a high heat flux (i.e. $50 \mathrm{~kW} / \mathrm{m}^{2}$ ) for burning, and therefore fuel ignition is only possible during an active flaming fire with a high heat transfer (White and Zipperer 2010).

The HRR curves (Fig. 3) highlighted the significant differences in combustibility between dead and decaying plant parts (Table 3). Differences in live parts in shrubs of different ages were not significant, and the HRR curves were similar (Fig. 3). Use of such a powerful ignition source $\left(50 \mathrm{~kW} / \mathrm{m}^{2}\right)$ may have hindered detection of differences between samples because rapid combustion occurs (due to the porous holder) regardless of any differences in the samples (White and Zipperer 2010). The results showed that gorse presented a bench-scale PHRR within the upper range of PHRR values (190-200 kW/m ${ }^{2}$ for live parts and 205-330 kW/m ${ }^{2}$ for dead and decaying parts) reported for bench-scale tests. For example, Weise et al. (2005) observed PHRR ranging from 24 to $166 \mathrm{~kW} / \mathrm{m}^{2}$ for green plant parts, from 88 to $302 \mathrm{~kW} / \mathrm{m}^{2}$ for oven-dried fuels and from 52 to $310 \mathrm{~kW} / \mathrm{m}^{2}$ for whole plants (intermediate-scale biomass calorimeter). Dibble et al. (2007) obtained PHRR values ranging from 30 to $397 \mathrm{~kW} / \mathrm{m}^{2}$ (FMC $\left.=7-10 \%\right)$ in individual tests. The RTI was significantly higher for dead parts than for other plant parts (Table 3). In addition, the absence of active combustion in 1-year-old gorse in fullscale tests with a low ignition source again confirms the significant effect of FMC and physiology (presence or not of dead and decaying parts). In fact, despite the different methods used, the RTI of dead parts measured in benchscale tests reached the same value $\left(27^{\circ} \mathrm{C} / \mathrm{s}\right)$ as the RTI of 5 year-old shrubs measured in full-scale tests, suggesting a relationship between the combustibility of dead parts and the combustibility of the whole plant, at least in an initial propagation phase (Anderson and Anderson 2010). The rapid combustion in full-scale tests generated a very high flame $\left(4 \mathrm{~m}\right.$ ) and high flame temperatures (above $900^{\circ} \mathrm{C}$ ) so that the efficacy of fuel treatment as regards reducing fire hazard is extremely low 5 years after prescribed burning (Marino et al. 2011).

The results of bench- and full-scale tests (Tables 3 and 4 and Fig. 4) confirmed that moisture content is a major fuel characteristic affecting the sustainability of plant combustion, as also reported by Anderson and Anderson (2010), White and Zipperer (2010) and Marino et al. (2011). The results suggest that sustainability is increased by physiological changes in gorse resprouts 1 to 5 years after prescribed burning, mainly because of the presence of dead and decaying parts with lower moisture contents. The average values of AEHC and THR were within the average range reported for bench-scale tests. No significant correlation between $\mathrm{GHC}$ and the other sustainability variables was detected (non-parametric Pearson correlation). The chemical differences between live fuel from 1-year-old (less lignified) and 5-year-old resprouts, measured in oxygen bomb tests (GHC, Table 3), did not affect the other 
sustainability variables. The results suggest that evaluation of flammability in an oxygen bomb calorimeter (e.g. Nuñez-Regueira 2004) may overestimate the differences due to physiological changes (chemical), confirming the greater importance of gas diffusion through the fuel (physical process) during a rapid flaming phase than the chemical characteristics of plant parts (Babrauskas 2006; Schemel et al. 2008; Madrigal et al. 2011a). Moreover, there were no significant differences in FD between plant parts (Table 3), but there were significant differences in AEHC and THR, suggesting that moisture content alters the combustion process and therefore does not simply act as an inert diluent (Babrauskas 2006). The results of full-scale tests revealed a lower AEHC than in previous studies (Weise et al. 2005; Babrauskas 2006). In the present study, the absence of a radiant heater and the air flow across the fuel specimen (outdoor wind tunnel) may have led to convective cooling of the plant, thus decreasing incremental growth of the burning area and HRR (see Eq. 2) in comparison with the full-scale calorimeter tests performed under indoor conditions (White and Zipperer 2010).

Very high consumability was observed at both scales (Tables 3 and 4). The full-scale test revealed a higher residual mass fraction, although of the same order of magnitude as in the bench-scale tests and higher than the range reported for wood material $(20-30 \%)$. The diameter of burnt residues was $4.13 \pm 0.39 \mathrm{~mm}$ (mean \pm standard error); therefore, all fine fuel was consumed. The results suggest that gorse is almost completely consumed (leaves, twigs and fine stems) when propagation and combustion processes are sustained and that FMC does not affect this process in finer fuels $(<10 \mathrm{~mm}$; Table 3$)$.

The present study showed that the growth of gorse resprouts after prescribed burning generates a large number of unfavourable characteristics in a short period of time, according to the criteria reported by White and Zipperer (2010) when considering fire resistance of a plant: accumulation of fuel (including dead twigs, branches and leaves), dry or dead undergrowth, dry leathery leaves, very fine leaves, dense and compact form, abundant and dense foliage. Etlinger and Beall (2004) suggested that assessment of 'fire-safe' plants can be carried out by sampling two characteristics: foliage moisture content and fraction of foliar mass with the plant exposed to water stress conditions. These authors not only suggested that any plant in which the foliage desiccates can be a fire hazard but also emphasized that flammability is strongly dependent on fullscale structural changes related to plant age (necromass fraction, bulk density, etc.). The present results are consistent with the findings of these authors and also demonstrate the importance of determining the flammability not only from tests in plant parts but also from tests conducted in whole plants.

\section{Conclusions and recommendations}

The flammability of gorse resprouts generated after prescribed burning was evaluated in the laboratory at two different scales: bench-scale (plant parts) and full-scale (whole plants). The results showed the importance of the effect of the different scales and types of methods used to determine the flammability of forest fuels, highlighting the complexity of comparing both types of results. Only full-scale experiments can provide a proper estimation of the flammability that can be expected in natural conditions. Bench-scale experiments are more appropriate to analysing physical processes and how different factors (fuel moisture content, chemical composition, fuel element size) may affect the flammability of the whole plant, but they are limited in that the distribution of the fuel elements is not that of the plant in natural conditions. However, despite these limitations, some useful conclusions can be reached from the complementarities existing between both experimental methodologies.

The results regarding ignitability were highly dependent on the initial heat transferred by the ignition source, which may underestimate the effect of moisture content (e.g. ignition success) when using high levels of heat flux in bench-scale tests. Although the combustibility varied according to the experimental device used, the results indicate that this parameter appears to be more dependent on the dead fraction than on the characteristics of live plant parts (e.g. live moisture content). Fire sustainability appears to be more closely related to physical characteristics (e.g. entry of air through the fuel sample), indicating the potential overestimation of the effect of chemical changes in some bench-scale tests (i.e. based on oxygen bomb results). In contrast, consumability in terms of residual mass fraction was similar at both scales, although mass loss rate was lower in bench-scale than in full-scale tests.

From the point of view of shrubland management, the results showed that the rapid physiological and structural changes that take place in gorse resprouts after prescribed burning reduce the efficacy of this treatment in controlling fire hazard in this kind of vegetation. Most of these changes may appear within 5 years after burning, during which time shrub cover can reach more than $95 \%$ (Marino et al. 2011). Some authors have proposed creating a mosaic of regenerated shrub of different ages to reduce fuel continuity and minimize the impact of wildfires. Optimization of the temporal and spatial pattern of fire application is required for a successful prescribed burning. The results suggest the need for intensive management of gorse shrubland to maintain the plants at a very young age $(<5$ years old). The combination of prescribed burning followed by controlled grazing may be an effective technique. However, further research is required to enable practical recommendations for reducing fire hazard in different types of shrubland ecosystems. 
Acknowledgements We thank Antonio Arellano from the Departamento de Protección Ambiental, CIF-Lourizán (Forest Research Center of Lourizán, Spain) for field assistance. We acknowledge the critical reviews of two anonymous referees who helped improve this manuscript. The work carried out in this article was supported by the National Institute for Agricultural Research (INIA) from the Spanish Ministry of Science and Innovation and cofounded by FEDER funds (Project RTA05-00244-C2-02 and RTA2009-00153-C03-02) and by the European Commission (Integrated Project FIRE PARADOX FP6018505). Participation of Eva Marino in the study was possible through a PhD scholarship funded by INIA.

\section{References}

Anderson HE (1970) Forest fuel ignitability. Fire Technol 6:312-319 Anderson SAJ, Anderson WR (2010) Ignition and fire spread thresholds in gorse (Ulex europaeus). Int $\mathrm{J}$ Wildland Fire 19:589-598

Babrauskas V (2002) The cone calorimeter. In: Society of fire Protection Engineering (ed), SFPE Handbook of Fire Protection Engineering, 3rd edition. National Fire Protection Association, Quincy, Massachusetts, pp 3-63 - 3-81

Babrauskas V (2006) Effective heat of combustion for flaming combustion of conifers. Can J For Res 36:659-663

Baeza MJ, De Luis M, Raventós J, Escarré A (2002) Factors influencing fire behaviour in shrublands of different stand ages and the implications for using prescribed burning to reduce wildfire risk. J Environ Manag 65:199-208

Baeza MJ, Raventós J, Escarré A, Vallejo VR (2003) The effect of shrub clearing on the control of fire-prone species Ulex parviflorus. For Ecol Manag 186:47-59

Beverly JL, Wotton BM (2007) Modelling the probability of sustained flaming: predictive value of fire weather index components compared with observations of site weather and fuel moisture conditions. Int J Wildland Fire 16:161-173

Calvo L, Tárrega R, De Luis E (2002) The dynamics of Mediterranean shrubs species over 12 years following perturbations. Plant Ecol 160:25-42

De Luis M, Baeza MJ, Raventós J, González-Hidalgo JC (2004) Fuel characteristics and fire behaviour in mature Mediterranean gorse shrublands. Int J Wildland Fire 13:79-87

Dibble AC, White RH, Lebow PK (2007) Combustion characteristics of north-eastern USA vegetation tested in the cone calorimeter: invasive versus non-invasive plants. Int J Wildland Fire 16:426443

Doran JD, Randall CK, Long AJ (2004) Fire in the wildland-urban interface: selecting and maintaining firewise plants for landscaping. University of Florida, Institute of Food and Agricultural Services, Florida Cooperative Extension Service Circular 1445, Gainesville, FL

Enninful EK, Torvi DA (2005) Effect of moisture on heat release and smoke production of vegetation. Proceedings of the Spring Technical Meeting, the Combustion Institute Canadian Section, Halifax, NS, 16-18 May

Etlinger MG, Beall FC (2004) Development of a laboratory protocol for fire performance of landscape plants. Int $\mathrm{J}$ Wildland Fire 13:479-488

Fernandes PM, Botelho HS (2003) A review of prescribed burning effectiveness in fire hazard reduction. Int J Wildland Fire 12:117128

Ganteaume A, Lampin-Maillet C, Guijarro M, Hernando C, Jappiot M, Fonturbel T, Pérez-Gorostiaga P, Vega JA (2009) Spot fires: fuel bed flammability and capability of firebrands to ignite fuel beds. Int J Wildland Fire 18:951-969
Hoshovsky M (1989) Element stewardship abstract for Ulex europaeus gorse. The Nature Conservancy, TNC-ESA, Arlington

International Organization for Standardization (1995) Determination of the heat of combustion (calorific value) (ISO 1716). International Organization for Standardization, Geneva

Madrigal J, Hernando C, Guijarro M, Díez C, Marino E, De Castro AJ (2009) Evaluation of forest fuel flammability and combustion properties with an adapted mass loss calorimeter device. J Fire Sci 27:323-342

Madrigal J, Villanueva S, Hernando C, Guijarro M, Díez C, Martínez I, Marino E, Barrio A, López M, Mordillo I (2010) Estimation of heat release rate of forest fuels during rapid flaming combustion: comparison between cone calorimeter and mass loss calorimeter devices. Proceedings of the 6th International Conference on Forest Fire Research, ADAI, University of Coimbra, Coimbra, Portugal, 15-18 November

Madrigal J, Guijarro M, Hernando C, Díez C, Marino E (2011a) Effective heat of combustion for flaming combustion of Mediterranean forest fuels. Fire Technol 47:461-474

Madrigal J, Guijarro M, Hernando C, Díez C, Marino E (2011b) Estimation of peak heat release rate of a forest fuel bed in outdoor laboratory conditions. J Fire Sci 29:53-70

Marino E, Madrigal J, Guijarro M, Hernando C, Díez C, Fernández C (2010) Flammability descriptors of fine dead fuels resulting from two mechanicals treatments in shrubland: a comparative laboratory study. Int J Wildland Fire 19:314-324

Marino E, Guijarro M, Hernando C, Madrigal J, Díez C (2011) Fire hazard after prescribed burning in a gorse shrubland: implications for fuel management. J Environ Manag 92:1003-1011

Martin RE, Gordon DA, Gutierrez MA, Lee DS, Molina DE, Schroeder RA, Sapsis DB, Stephens SL, Chambers M (1994) Assessing the flammability of domestic and wildland vegetation. Proceedings of the 12th Conference on Fire and Forest Meteorology, Society of American Foresters, Bethesda, MD, Jekyll Island, GA, 26-28 October, pp 130-137

Núñez-Regueira L, Rodríguez-Añón J, Proupin J (2004) Using calorimetry for determining the risk indices to prevent and fight forest fires. Thermochim Acta 422:81-87

Pausas JG, Llovet J, Rodrigo A, Vallejo R (2008) Are wildfires a disaster in the Mediterranean basin? A review. Int J Wildland Fire 17:713-723

Pereiras J, Casal M (2002) Dynamics of an Ulex shrubland community subjected to prescribed burning. In: Trabaud L, Prodon R (eds) Fire and biological processes. Blackhuys, Leiden, pp 43-56

Potts JB, Marino E, Stephens SL (2010) Chaparral shrub recovery after fuel reduction: a comparison of prescribed fire and mastication techniques. Plant Ecol 210:303-315

Schemel CF, Simeoni A, Biteau H, Rivera JD, Torero JL (2008) A calorimetric study of wildland fuels. Exp Therm Flu Sci 32:1381-1389

Smith EE (1996) Heat release rate calorimetry. Fire Technol 32:334-347

Sullivan AL (2009) Wildland surface fire spread modelling, 19902007. 1: Physical and quasi-physical models. Int J Wildland Fire 18:349-368

Weise DR, White RH, Beall FC, Etlinger M (2005) Use of the cone calorimeter to detect seasonal differences in selected combustion characteristics of ornamental vegetation. Int $\mathrm{J}$ Wildland Fire 14:321-338

White RH (1987) Effect of lignin content and extractives on the higher heating value of wood. Wood Fiber Sci 19:446-452

White RH, Zipperer WC (2010) Testing and classification of individual plants for fire behaviour: plant selection for the wildland-urban interface. Int J Wildland Fire 19:213-227

Wickström U, Göransson U (1987) Prediction of heat release rates of surface materials in large-scale fire tests based on cone calorimeter results. J Test Eva 15:364-370 